\title{
1 \\ Human Colonic Microbiology and the Role of Dietary Intervention: Introduction to Prebiotics
}

\author{
Claire L. Vernazza, Bodun A. Rabiu and Glenn R. Gibson
}

\subsection{Acquisition and Development of the Human Gut Flora}

The human embryo is virtually sterile, but at birth microbial colonisation of the gastrointestinal tract occurs, with the neonate receiving an inoculum from the birth canal (Fuller, 1991; Zetterström et al., 1994). The microbial pattern that ensues depends on the method of delivery (Beritzoglou, 1997; Salminen et al., 1998a) and hygiene precautions associated with parturition (Lundequist et al., 1985). In addition to characteristic vaginal flora such as lactobacilli, yeast, streptococci, staphylococci and Escherichia coli, the neonate is also likely to come into contact with faecal microorganisms and skin bacteria during birth (Fuller, 1991). Furthermore, inoculation from the general environment and other external contacts may also be significant, especially during Caesarean delivery (Beritzoglou, 1997; Gronlund et al., 1999). During the acquisition period, some bacteria transiently colonise the gut whilst others survive and grow to form the indigenous microflora. Consequently, the neonatal gut experiences a rapid succession of microfloral components in the first days to months of development, selected for, initially, by luminal redox potential (Eh) but more frequently reported as being due to the feeding regime that follows birth (Zetterström et al., 1994). Initial colonisers utilise any available oxygen, usually by $48 \mathrm{~h}$, creating an environment sufficiently reduced to allow succession by obligate anaerobes, mainly those belonging to the bifidobacteria, bacteroides and clostridia groups. At this stage, it appears that 
feeding methods have a significant influence on the relative proportions of bacteria that establish in the infant gut. Historically, breast-fed infants are thought to have relatively higher proportions of bifidobacteria than formula-fed babies of the same age, who possess a more complex composition (Fuller, 1991). Such purported differences have been linked with a lower risk of gastrointestinal, respiratory and urinary tract infections in breast-fed infants (Kunz and Rudloff, 1993). However, as the nature of commercial feeds has altered in recent times, the bifidobacterial predominance seen during breast feeding is less definitive. Nevertheless, such observations demonstrate the ability of diet to influence the gut microbiota composition and the possibilities for influencing health as a result. This has formed the basis for dietary intervention procedures that are extremely popular today (see later).

By the end of weaning there is a drop in the frequency of bifidobacteria. With the introduction of solid foods and by about 2 years after birth, infants start to adopt microflora profiles in proportions that approximate to those seen in adults (Fuller, 1991). The populations then seem to be relatively stable ( $>99 \%$ anaerobic), aside for perturbations by diet and habit, until advanced ages when a significant decline in bifidobacteria, plus increases in clostridia and enterobacteriaceae are reported (Mitsuoka, 1990).

\subsection{The Human Gastrointestinal Tract and its Microflora}

Microorganisms occur along the whole length of the human alimentary tract with population numbers and species distribution characteristic of particular regions of the gut (Macfarlane et al., 1997). After the mouth, colonisation is markedly influenced, in part by luminal $\mathrm{pH}$, and by the progressively slower transit of food materials towards the colon. The movement of digesta through the stomach and small intestine is rapid (ca. 4-6 h), when compared with a typical colonic transit time of around 48-70 h for adults (Macfarlane and Gibson, 1994). This allows the establishment of a complex and relatively stable bacterial community in the large intestine (Table 1.1). The near neutral $\mathrm{pH}$ and the relatively low absorptive state of the colon further encourages extensive microbial colonisation and growth (Macfarlane et al., 1997; O'Sullivan, 1996).

The human large intestine consists of the caecum, ascending colon, transverse colon, descending colon, sigmoid colon and rectum (Macfarlane and Macfarlane, 1997) (Figure 1.1). Through the microflora, the colon is capable of complex hydrolyticdigestive functions (Cummings and Macfarlane, 1991). This involves the breakdown of dietary components, principally complex carbohydrates, but also some proteins, that are not hydrolysed nor absorbed in the upper digestive tract (Macfarlane et al., 1992). Carbohydrate availability subsequently diminishes as dietary residues pass from the proximal colon to the transverse and distal bowel.

For persons living on Western-style diets, the microbial biomass makes up over $50 \%$ of colonic contents. There are more than 500 different culturable species of indigenous bacteria present in the adult large intestine comprising around $10^{12}$ bacteria per gram dry weight (Moore et al., 1978; Simon and Gorbach, 1984). A summary of the principal bacterial groups present is shown in Table 1.2.

In very general terms, intestinal bacteria can be divided on the basis of whether they can exert health promoting, benign or potentially harmful activities in their host (Gibson 


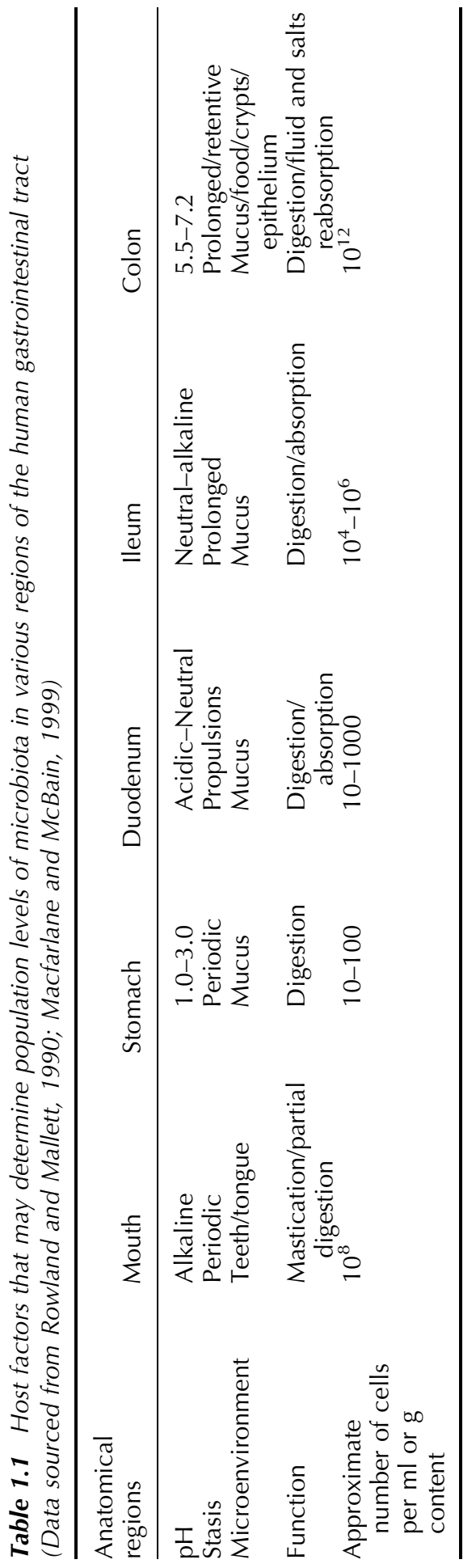




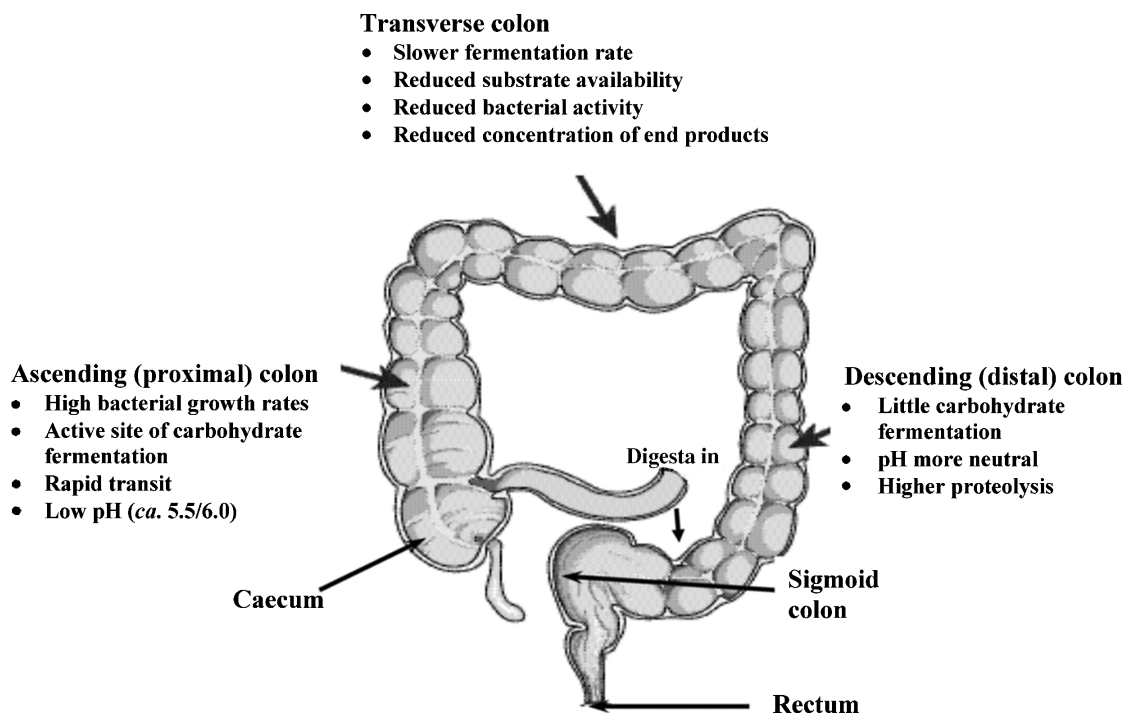

Figure 1.1 Regions of the human large intestine with corresponding bacterial activities and physiological differences (Adapted from Cummings and Macfarlane, 1991). Modified with the permission of the authors from Journal of Applied Bacteriology, Vol 70, Cummings J.H. and Macfarlane, G.T., The control and consequences of bacterial fermentation in the human colon: a review, pp. 443-459, 1991, by permission of Blackwell Publishing

and Roberfroid, 1995). The most obvious pathogens are strains of E. coli and clostridia. Pathogenic effects include diarrhoeal infections and putrefaction whereas beneficial aspects may be derived simply by improved the digestion/absorption of essential nutrients. This leads towards a consideration of factors that may influence the flora composition in a manner than can impact upon health.

The multiplicity of substrates is probably the single most important determinant for dynamics and stability of species existing in the large bowel (Gibson and Collins, 1999). Whilst these are mainly produced by dietary residues, there is appreciable contribution from host secretions like mucins. The colonic microflora derive substrates for growth from the diet (e.g. nondigestible oligosaccharides, dietary fibre, undigested protein reaching the colon) and from endogenous sources such as mucin, the main glycoprotein constituent of the mucus which lines the walls of the gastrointestinal tract (Rowland and Wise, 1985). The vast majority of bacteria in the colon are strict anaerobes and thus derive energy from fermentation (Macfarlane and McBain, 1999). The two main fermentative substrates of dietary origin are nondigestible carbohydrates (e.g. resistant starch, nonstarch polysaccharides and fibres of plant origin and nondigestible oligosaccharides) and protein which escapes digestion in the small intestine. Of these, carbohydrate fermentation is more energetically favourable, leading to a gradient of substrate utilisation spatially through the colon (Macfarlane et al., 1992). The proximal colon is a saccharolytic environment with the majority of carbohydrate entering the colon being fermented in this region. As digesta moves through towards the distal colon, carbohydrate availability decreases and protein and amino acids become a more dominant metabolic energy source for bacteria in the distal colon (Macfarlane et al., 1992). Overall 


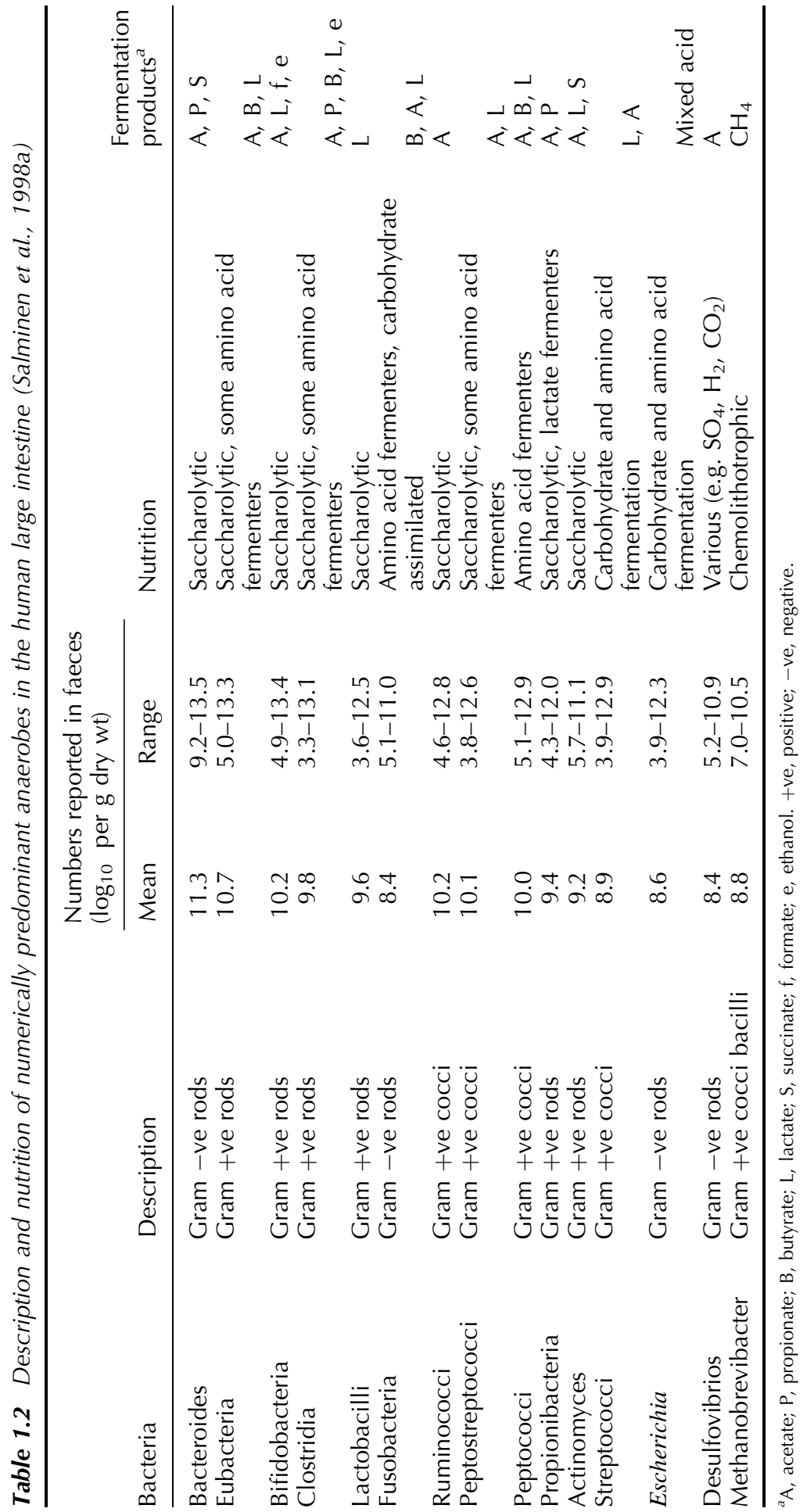


however, the principal substrates for bacterial growth are dietary carbohydrates. It has been estimated that about 10 to $60 \mathrm{~g}$ per day of dietary carbohydrate reaches the colon (Englyst and Cummings, 1986, 1987). A large proportion of this carbohydrate is made up of resistant starch (i.e. starch recalcitrant to the activities of human amylases). Resistant starch is readily fermented by a wide range of colonic bacterial species including members of the Bacteroides spp., Eubacterium spp. and the bifidobacteria (Englyst and Macfarlane, 1986). The remainder of the carbohydrate entering the colon is comprised of nonstarch polysaccharides (about 8-18 g per day), unabsorbed sugars, e.g. raffinose, stachyose and lactose (about 2-10 g per day) and oligosaccharides such as fructooligosaccharides, xylooligosaccharides, galactooligosaccharides (about 2-8 g per day) (Bingham et al., 1990; Gibson et al., 1990; Cummings and Macfarlane, 1991). The degree to which these carbohydrates are broken down by the gut microflora varies greatly. Unabsorbed sugars entering the colon are readily fermented and persist for only a short time in the proximal colon (Hudson and Marsh, 1995). Some sugars such as raffinose may have a more selective fermentation (being mainly assimilated by bifidobacteria and lactobacilli) while others support the growth of a range of colonic bacteria. Similarly, nondigestible oligosaccharides reaching the colon display different degrees of fermentation. Certain oligosaccharides such as fructooligosaccharides, galactooligosaccharides and lactulose may be fermented preferentially by bifidobacteria, which has given rise to the concept of prebiotics (discussed later) (Gibson and Roberfroid, 1995). Nonstarch polysaccharides include pectin, arabinogalactan, inulin, guar gum and hemicellulose, which are readily fermented by the colonic microflora, and lignin and cellulose, which are much less fermentable (Lewis et al., 2001). Endogenous carbohydrates, chiefly from mucin and condroitin sulphate, contribute about 2-3 g per day of fermentable substrate (Quigley and Kelly, 1995). The main saccharolytic species in the colonic microflora belong to the genera Bacteroides, Bifidobacterium, Ruminococcus, Eubacterium, Lactobacillus and Clostridium (Gibson, 1998). Protein and amino acids are also available for bacterial fermentation in the colon. Approximately $25 \mathrm{~g}$ of protein enters the colon daily (Macfarlane and Macfarlane, 1997). Other sources of protein in the colon include bacterial secretions, sloughed epithelial cells, bacterial lysis products and mucins. The main proteolytic species belong to the bacteroides and clostridia groups.

Carbohydrates in the colon are fermented to short chain fatty acids (SCFA), principally, acetate, propionate and butyrate (Cummings, 1981, 1995) and a number of other metabolites such as the electron sink products lactate, pyruvate, ethanol, succinate as well as the gases $\mathrm{H}_{2}, \mathrm{CO}_{2}, \mathrm{CH}_{4}$ and $\mathrm{H}_{2} \mathrm{~S}$ (Levitt et al., 1995). SCFA are rapidly absorbed by the colonic mucosa and contribute towards energy requirements of the host (Cummings, 1981; Englehardt et al., 1991). Acetate is mainly metabolised in human muscle, kidney, heart and brain, while propionate is cleared by the liver, and is a possible gluceogenic precursor which suppresses cholesterol synthesis. Butyrate, on the other hand, is metabolised by the colonic epithelium where it serves as a regulator of cell growth and differentiation (Cummings, 1995). Protein reaching the colon is fermented to branched chain fatty acids such as isobutyrate, isovalerate and a range of nitrogenous compounds. Unlike carbohydrate fermentation, some of these end products may be toxic to the host, e.g. ammonia, amines and phenolic compounds (Macfarlane and Macfarlane, 1995). Excessive protein fermentation, especially in the distal colon, has therefore been linked with disease states such as colon cancer, which generally starts in this region of the 
colon before progressing proximally along the colon. Examples include bowel cancer and ulcerative colitis.

\subsubsection{Influence of Diet on Microflora Activity and Health}

Metchnikoff (1907) hypothesised that the onset of senility and shortening of life span resulted from putrefaction in the large bowel. In his opinion, the consumption of soured (fermented) milks was a progenitor for improved gastrointestinal health and the prolongation of life in Bulgarian populations. It is now known that bacterial activity in the human colon is involved in a number of disease states. The large intestine can harbour pathogens that are either part of the resident flora or exist as transient members (Gibson et al., 1997). Attachment and overgrowth of the pathogens generally results in acute diarrhoeal infections, however more chronic forms of intestinal disease also occur (Gibson et al., 1997; Gionchetti et al., 2000). These include inflammatory bowel diseases (ulcerative colitis and Crohn's disease) (Chadwick and Anderson, 1995), colon cancer (Rowland, 1988; Rumney et al., 1993) and pseudomembranous colitis (Duerden et al., 1995). To varying extents, each has been linked into microflora composition and activities, and thereby diet as this provides the major source for their growth. The concept of probiotics was developed to influence the gut microbiota in a beneficial manner.

\subsection{Probiotics}

The word probiotic comes from the Greek 'for life' and is defined as 'a live microbial food supplement that is beneficial to host health' (Fuller, 1989). The definition of probiotics has evolved over the years, but the consensus designates probiotics as "nonpathogenic, live microbial, mono- or mixed-culture preparations, which, when applied to humans or animals in high enough doses, beneficially affect the host by improving the intestinal microbial balance and its properties' (Fuller, 1989; Havenaar et al., 1992; Havenaar and Huis in't Veld, 1992; Salminen et al., 1998a). Accepted characteristics for probiotics are listed in Table 1.3. Hitherto, evaluating their ability to compete effectively with resident and established microorganisms for available nutrients in a multi-substrate gut environment, is one attribute not thoroughly investigated in the selection and implementation of probiotics. Their survivability may be enhanced greatly in the presence of prebiotic carbohydrates proven to select for useful species of Bifidobacterium and Lactobacillus (Kailasapathy and Chin, 2000). Such a mixture may improve therapeutic potential in the gastrointestinal tract, and are defined as synbiotics (see later).

The most widely used bacteria as probiotics are the lactobacilli and bifidobacteria but products incorporating other organisms such as Gram positive cocci, bacilli, yeasts and $E$. coli have also been applied (Holzapfel and Schillinger, 2002). Probiotic preparations are widely available to consumers as powders, tablets, drinks and fermented dairy products.

Safety is of utmost concern when selecting probiotics. Whilst many lactic acid bacteria, used in traditional fermented food products such as yoghurt, sauerkraut and kefir, have a long history of safe use, the recent explosion of probiotic-containing 
Table 1.3 Desirable properties of probiotic bacteria (Data sourced from Salminen et al., 1998a)

\begin{tabular}{|c|c|}
\hline Probiotic strain characteristics & Functional properties \\
\hline $\begin{array}{l}\text { Human origin, if intended for } \\
\text { humans }\end{array}$ & $\begin{array}{l}\text { Species-dependent health effects and maintained } \\
\text { viability; applicability to functional and } \\
\text { clinical foods. }\end{array}$ \\
\hline Acid and bile stability & $\begin{array}{l}\text { Survival in the intestine, maintaining } \\
\text { adhesiveness and other colonization } \\
\text { properties }\end{array}$ \\
\hline $\begin{array}{l}\text { Adherence to human intestinal cells } \\
\text { and intestinal mucus glycoproteins } \\
\text { (mucin) }\end{array}$ & $\begin{array}{l}\text { Immune modulation, competitive exclusion } \\
\text { of pathogens }\end{array}$ \\
\hline $\begin{array}{l}\text { Competitive exclusion and } \\
\text { colonization of the human } \\
\text { intestinal tract }\end{array}$ & $\begin{array}{l}\text { Multiplication in the intestinal tract, competitive } \\
\text { exclusion of pathogens, stimulation of } \\
\text { beneficial microflora, immune modulation } \\
\text { by contact with } \\
\text { gut associated lymphoid tissue }\end{array}$ \\
\hline Production of antimicrobial substances & $\begin{array}{l}\text { Pathogen activation in the intestine, normalization } \\
\text { of the gut flora }\end{array}$ \\
\hline $\begin{array}{l}\text { Antagonism against cariogenic and } \\
\text { pathogenic bacteria }\end{array}$ & $\begin{array}{l}\text { Pathogen exclusion, prevention of pathogen } \\
\text { adhesion, normalization of gut flora, } \\
\text { normalization of oral microflora }\end{array}$ \\
\hline Safety in food and clinical use & $\begin{array}{l}\text { Accurate strain identification (genus, species, } \\
\text { strain) and chracterization, documented safety }\end{array}$ \\
\hline $\begin{array}{l}\text { Clinically validated and } \\
\text { documented health effects }\end{array}$ & $\begin{array}{l}\text { Dose-response data for minimum effective dosage } \\
\text { in different products and population groups }\end{array}$ \\
\hline
\end{tabular}

foodstuffs incorporating a wide variety of different strains calls for investigations into safety and tolerance. The USA Food and Drug Administration (FDA) run a system for all food additives whereby a long history of safe use (prior to 1958) or substantial scientific evidence can lead to 'generally regarded as safe' (GRAS) status. Lactobacilli are commonly given this status due to the largely nonpathogenic nature of this genus (Salminen et al., 1998b). This is also true for the bifidobacteria. To prove scientifically that a probiotic may be regarded as safe there are three levels of study: in vitro and animal studies can be of use in the first instance, but as these data will only pertain to the model system used, clinical trials are required. Controlled clinical trials have been used in safety assessments of probiotics and detailed measurements of many physiological parameters can be made. Thirdly, and possibly most reliably, history of safe use over a period of time can be studied retrospectively with the benefits of large data sets. One example of such a study investigated the consumption of Lactobacillus rhamnosus GG in Finland over a period of 11 years (Salminen et al., 2002). Collection and comparison of clinical isolates of lactobacilli from bacteraemia cases showed no correlation between ingestion of $L$. rhamnosus GG and bacteraemia.

Another criterion for selecting probiotic strains is resistance of the strain to stresses it will encounter on its journey throughout the gastrointestinal tract. To reach the desired site of action (e.g. the colon) a probiotic microorganism must pass through the highly acidic stomach and survive bile secretions into the small intestine. Moreover, it should compete well with the resident flora. In vitro tests provide the easiest method of 
discerning tolerance in these situations of various candidate probiotics, as gaining samples from the human stomach and small intestine is ethically questionable and practically difficult.

As an alternative to these model studies it is possible to assess probiotic survival via identification of the strain in faeces, overcoming the shortfalls of the model systems described above. The difficulty with this sort of study is identification of the strain of interest in the complex microbial communities found in faeces. Traditional agar plate methods fail to identify only one species and if this approach is used, then further testing of colonies is required. Microscopic examination, testing for excreted peptides and carbohydrate fermentation patterns (for example as determined by the Analytical Profile Index system) have had to be employed to be confident that the target species has been selected (Wolf et al., 1995). Yuki et al. (1999) developed monoclonal antibodies to detect their strain of interest and used these in an enzyme-linked imunosorbent assay (ELISA). Another approach is to add genetic markers to the strain, such that they can be selected in mixed culture. One study used a spontaneous mutant of the strain against rifampicin and streptomycin, with a transposon-encoded insertion for sucrose degradation (Klijn et al., 1995). This combination of genetic elements made the strain easily selectable on agar plates, but tampering with the genetics of the bacteria can change its overall properties. In the same study, polymerase chain reaction (PCR) was used to check the identification of colonies, targeted to a nisin gene encoded on the transposon. Alternatives to PCR for confirmation of colony identity have also included randomly amplified polymorphic DNA-PCR (RAPD-PCR) (Alander et al., 2001; Fujiwara et al., 2001). In this approach, a single simple primer is used to generate many small amplicons from the same DNA molecule. When genetic differences are present (i.e. when the DNA is from a different bacterium) the primer will bind to different sites and different sised amplicons may occur. Running these amplicons on a gel and comparing the presence or absence of different sised bands will reveal whether the recovered species is the same as the fed species. To negate the need for culturing samples, Satokari et al. (2001), used PCR linked to denaturing gradient gel electrophoresis (PCR-DGGE) to detect the presence of their probiotic in faeces. The method amplifies a region of the $16 \mathrm{~S}$ rDNA via PCR with a G-C rich 'clamp' at one end of the amplicon. The products are then ran on a polyacrylamide gel with a gradient of the denaturants formamide and urea (a temperature gradient can also be used in a similar manner and the technique is then known as TGGE). Amplicons are denatured as a function of their G-C content and sequence but the two strands are held together by the G-C clamp. The position on the gel can be used against markers, or the bands subsequently excised and sequenced to identify species. However, this approach can only be used qualitatively. A method by which probiotic bacteria can be quantified using molecular techniques is fluorescent in situ hybridisation (FISH). Oligonucleotide probes are hybridised to samples which are examined with the aid of fluorescence microscopy or flow cytometery (Langendijk et al., 1995). This technique has been mainly used to quantify bacterial genera or groups of bacteria, but species-specific probes have been developed (McCartney, 2002). However, to use this technique successfully, the target organism must make up at least $1 \%$ of the population due to the detection limits of this method. While important advances have been made in probiotic detection and discrimination, their recovery in faeces is not a definite indicator of gut colonisation or persistence. 
Another factor that is important when selecting probiotics is the antibiotic resistance profile. Both benefits and risks are present when a strain is resistant to antimicrobial treatment. Resistance to drugs used to treat human infections could be advantageous, as the probiotic would not be affected whereas the resident microflora could suffer the loss of some of its members, allowing an overgrowth of potentially pathogenic organisms. However, the mobility of genetic elements on which antibiotic resistance genes can be carried could be problematic. Lactobacilli and enterococci can carry their antibiotic resistance genes on plasmids which are transferable to other bacteria (Salminen et al., 1998b). Transfer of resistance to other organisms could be hazardous in that antimicrobials used to treat conditions caused by the transformed bacteria may become ineffective.

A further point for consideration is the ability of a strain to colonise the gut epithelium. In most trials with probiotics, cells are washed out and are no longer detectable in faeces after 1 week and following just a matter of days of cessation of treatment (Jacobsen et al., 1999; Tannock et al., 2000; Satokari et al., 2001). This property can be investigated using cultured cells and applying probiotic bacteria. Using these methods it has been found that lactobacilli are generally more adherent than bifidobacteria (Dunne, 2001).

Delivery method should also be a consideration. Shelf life and survival in the given medium are critical for successful delivery of live cells to the colon. Milk products have been found not only to maintain viability but to support growth of bifidobacteria. A study by Shin et al. (2000), showed that some viability was maintained after 4 weeks at $4{ }^{\circ} \mathrm{C}$ in skimmed milk, and that the degree of viability could be greatly increased by adding various oligosaccharides.

Together with the barriers to product integrity (e.g. maintaining high counts of anaerobic bacteria and avoiding contamination) as well as within the intestinal tract, prebiotics have been developed. The attempt is to use nonviable food ingredients to fortify selected components of the indigenous microbiota, hence overcoming survivability issues. However, for prebiotics to be successful health advantages should be targeted. This is an advanced area of probiotic research and will be discussed below.

\subsection{Health Benefits of Probiotics}

Common definitions of probiotics often include references to health benefits, so success is ultimately likely to be dependent on such outcomes.

\subsubsection{Inhibition of Pathogens}

A concept known as colonisation resistance, in which the indigenous flora creates a barrier preventing new and possibly pathogenic organisms from invading, normally protects from disease (Macfarlane and McBain, 1999). Unfortunately, this fragile ecosystem can be disrupted, for example by treatment with antibiotics, allowing the growth of undesirable organisms. Payne et al. (2003) found that the addition of Lactobacillus plantarum to an in vitro model gut challenged with tetracycline, caused resistance to Candida albicans to increase. This resistance may have been due to restoration of normal colonisation resistance by the addition of lactobacilli to the 
depleted flora, or via a direct antimicrobial action. Protection from various gastrointestinal pathogens has been widely reported. Co-culture experiments have shown bifidobacteria to inhibit various gut pathogens (Bruno and Shah, 2002). In this research, the presence of supernatant from culture medium of the bifidobacteria was sufficient to cause inhibition but when the $\mathrm{pH}$ was adjusted to 7, antimicrobial effects diminished. Lactic acid bacteria produce organic acids (Alvarez-Olmos and Oberhelman, 2001) such as lactate and acetate which acidify the surroundings to a $\mathrm{pH}$ at which these pathogenic organisms are unable to effectively compete. However, there are other mechanisms by which probiotics can be antipathogenic. Various lactic acid bacteria produce antimicrobial peptides, which are secreted into the growth medium (Anderssen et al., 1998). Competition for nutrients can also decrease pathogenic bacteria in the gastrointestinal tract. This was shown by Yamamoto-Osaki et al. (1994), where amino acids were depleted in cultures where inhibition of Clostridium difficile was noted and not where $C$. difficile was not inhibited by the addition of protective faecal flora from infants. Clostridium botulinum is another member of the clostridia that can cause disease that can be treated with probiotics (Sullivan et al., 1988). Infant botulism is a disorder whereby botulinal neurotoxin is produced by $C$. botulinum spores that have been ingested and colonised the infant gut, before a more protective adult flora becomes established (Salyers and Whitt, 1994). This is different to food-borne botulism where only the toxin is ingested. In vitro data have shown that bifidobacteria and Enterococcus faecalis isolated from human infant faeces can be inhibitory to C. botulinum (Sullivan et al., 1988).

Other conditions have also been successfully treated through probiotics. Rotavirus is a common cause of acute diarrhoea in children and is a serious problem worldwide. Probiotic therapy using species such as Lactobacillus rhamnosus GG, L. casei subsp. Shirota and Bifidobacterium lactis Bb-12 have shortened symptoms (Gorbach, 2002; Ouwehand et al., 2002; Saarela et.al., 2002). It has also been shown that application of Bifidobacterium bifidum can also act prophylactically against rotavirus in hospitalised children.

E.coli is a normal resident of the human gastrointestinal tract. Some strains can cause disease in the gut or be transferred to the urinary tract where infection may develop. In a clinically reported case, Gerasimov (2004) successfully used Lactobacillus acidophilus to prevent further recurrence of $E$. coli urinary tract infection in a frequently affected child. E. coli can also be pathogenic in the gut environment when exogenous species appear. Enteropathogenic strains of E.coli are frequently responsible for travellers' diarrhoea. Two strains of Lactobacillus rhamnosus reduced the ability of these E. coli to adhere to cultured cells. Other enteropathogenic microorgamisms were also inhibited. Salmonella typhimurium adherence was inhibited by Lactobacillus johnsonii and Lactobacillus casei subsp. Shirota (Sullivan and Nord, 2002).

\subsubsection{Immune Stimulation}

Probiotic use can also stimulate the immune system. Cells in the colon regularly sample the microflora and there is an inherent tolerance to the commensal flora (Schiffrin and Brassart, 1999). However, the presence of exogenous Gram positive bacteria can induce the secretion of cytokines of a pro- or anti-inflammatory nature dependent upon the 
species (Cross, 2002). Pro-inflammatory cytokines include TNF $\alpha$, IL-12 and IFN- $\gamma$ which encourage migration of immune cells (Roitt et al., 1998). This type of reaction may be useful in the case of cancer where the immune response helps eliminate cancerous cells. Secretion of anti-inflammatory cytokines, such as IL-10, which inhibit the production of other cytokines may promote inflammation (Roitt et al., 1998) would be of help in the case of hypersensitivity, allergy and inflammatory bowel disease, whereby the inflammatory response is overactive (Saarela et al., 2002). IL-10 deficient mice develop colitis as a consequence of their inability to down-regulate the inflammatory response and it has been found that the feeding of lactobacilli can restore IL-10 levels and prevent onset of colitis (Sullivan and Nord, 2002). Severity of atopic dermatitis has been shown to decrease when lactobacilli are given. Other components of the immune system may be responsible for this, as in a study by Rosenfeldt et al. (2003) interleukins and IFN- $\gamma$ were unaffected but serum eosinophil cationic protein (released by granules in eosinophils during inflammation) levels decreased. Pathogens in the gut can be cleared with the help of immune stimulation as caused by probiotic organisms. In murine models, E. coli and Salmonella typhimurium clearance occurred more quickly upon treatment with L. casei, with a concomitant increase in intestinal IgA specific to the pathogen (Cross, 2002). Cross (2002) also noted that effects of probiotic administration on the immune system can reach further than the gastrointestinal tract and into other systems of the body, as illustrated by a faster clearance of bacterial and viral pathogens from the respiratory tract following probiotic feeding, accompanied by an increase in nonspecific phagocytic activity of alveolar macrophages and pathogen-specific serum IgG.

\subsubsection{Cholesterol Reduction and Cardiovascular Disease Risk}

In vitro and in vivo research has shown that probiotics may be able to lower serum cholesterol levels, although this is still a debatable area of research (Naruszewicz et al., 2002; Pereira et al., 2003). The mechanisms for this are currently unclear with many different hypotheses being proposed. Pereira and Gibson (2002) suggested four possible mechanisms: the production of propionate, assimilation of cholesterol by bacteria, binding of cholesterol to bacterial cell walls and enzymatic degradation. In experiments by Pereira et al. (2003) in vitro cholesterol levels were lowered by Lactobacillus fermentum. The authors suggested that in this case a high level of propionate and/or bile acid deconjugation were probable mechanisms. In a human study of cholesterol and cardiovascular disease risk factors, Naruszewicz et al. (2002) found that Lactobacillus plantarum was able to lower blood pressure, fibrinogen and LDL cholesterol and raise HDL cholesterol.

\subsubsection{Cancer}

Large bowel cancer is a leading cause of death in the western world, and whilst genetic predisposition can be a factor, diet can also play an important role in this disease (Rao, 1999). Meat can be converted to heterocyclic amines during the cooking process and the bacterial fermentation of protein produces amines and ammonia, which are toxigenic. The ingestion of vegetables can offer protection against colorectal cancer from compounds such as flavols, lycopenes, sulphur compounds, isoflavones, lignans, and saponins 
that can stimulate immunity, are antioxidants, or detoxify genotoxic compounds (Rao, 1999). Two enzymes that can produce carcinogens are $\beta$-glucuronidase in the host and flora and $\beta$-glucosidase in the microflora, although the latter is also responsible for catalysing the production of antimutagenic substances (Burns and Rowland, 2000). Lactic acid bacteria have been shown to reduce levels of both of these enzymes in faeces (Burns and Rowland, 2000). B. longum has also been shown to decrease the incidence of some tumours and completely inhibit other types of tumours in rat models (Reddy, 1999). This may be due to inhibition of an enzyme, orthinine decarboxylase, present in high levels in cancer or the blocking of expression of a tumour promoting gene, ras-21. Burns and Rowland (2000) also noted that, in vitro, some probiotic bacteria have the ability to bind carcinogens such as heterocyclic amines, but this seems to have no effect in vivo. In addition to these mechanisms immune stimulation, as discussed in section above, could be another mechanism of anticancer activity of probiotics.

\subsubsection{Other Health Benefits and Future Directions for Research}

In the case of lactose maldigestion (deficiency in $\beta$-galactosidase), fermented milk products are better tolerated than milk. This is due to the presence of lactic acid bacteria, which may posses this enzyme, in the fermented milk. The bacteria are lysed in the gastrointestinal tract and the enzyme may be released, allowing better digestion of lactose in the gut (Ouwehand et al., 2002). This mechanism could also be of use in the case of sucrose digestion in sucrase-deficient infants where Saccharomyces cerevisiae has been shown to act similarly (Marteau et al., 2001).

Irritable bowel syndrome (IBS) is a poorly defined disorder characterised by abdominal pain and a change in bowel habit with disordered defaecation and distension. Many causes have been suggested including an imbalance in the intestinal microflora. Studies in IBS patients have shown that a variety of probiotic organisms, including L. acidophilus (viable and heat-killed), Enterococcus faecium and L. plantarum to improve symptoms (Marteau et al., 2001; Saarela et al., 2002).

Due to their inherent tolerability it is thought that in the future probiotic bacteria could be used as vectors, expressing vitamins or insulin to those with deficiencies or genetically modified to act as oral vaccines, expressing viral antigens (Gorbach, 2002). Mucosal vaccination with lactobacilli may also be possible to stop the spread of HIV and other sexually transmitted diseases as research has shown a lack of lactobacilli populations in patients suffering from such diseases (Alvarez-Olmos and Oberhelman, 2001).

It is also hoped that the treatment of bacterial infections with probiotics instead of traditional antibiotics may reduce the increasing problem of multidrug resistance (Bengmark, 1998; Alvarez-Olmos and Oberhelman, 2001).

\subsection{Prebiotics}

A prebiotic is defined as 'a nondigestible food ingredient that beneficially affects the host by selectively stimulating the growth and/or activity of one or a limited number of bacteria in the colon and thus improves host health' (Gibson and Roberfroid, 1995). The stimulated bacteria should be of a beneficial nature, namely bifidobacteria and 
lactobacilli (Gibson et al., 1999). To have these effects, prebiotics must be able to withstand digestive processes before they reach the colon and preferably persist throughout the large intestine such that benefits are apparent distally (Gibson et al., 2004).

Lower molecular weight oligosaccharides have been the subject of recent interest because, apart from the nonstarch polysaccharides, they present themselves as the most portable source of carbon for colonic bacteria. When ingested, these carbohydrates are not digested in the small intestine and reach the ileocaecal region in a relatively unmodified form (Oku et al., 1984; Nilsson et al., 1988; Ellegard et al., 1997). In the colon they can act as dietary bulking agents or make up a percentage of available substrate for resident colonic bacteria, consequently, contributing towards a decrease in $\mathrm{pH}$ and the production of SCFA, effects that may result in reduced numbers of pathogenic microorganisms (Morisse et al., 1993).

Oligosaccharides are relatively short chain carbohydrates that occur widely in nature. They are typically found in the plant kingdom but have also been detected in relatively smaller quantities, as free sugars or glycoconjugates, in human milk and the colostrum of various animals (Bucke and Rastall, 1990). Primarily, they are retained as reserve sugars in seeds and tubers and used when growth begins, however their effects on gastrointestinal physiology in recent years has highlighted renewed significance to human health (Van Loo et al., 1999).

Certain oligosaccharides (Table 1.4) have all been reported, at varying concentrations, to have an ability to promote the growth of organisms whose metabolism have positive physiological consequences (Fuller and Gibson, 1998; Gibson et al., 2000). It may be possible to develop a range of such carbohydrates for incorporation into foods in a bid to improve their 'prebiotic effect'. This is especially true in the West where conventional diets only have relatively small quantities of oligosaccharides (ca. 2-5 g per day) consumed daily (Macfarlane and Cummings, 1991; Roberfroid et al., 1993). Fructooligosaccharides are well researched prebiotics which occur naturally in the diet (Table 1.5). A fuller description of prebiotic oligosaccharides is given elsewhere in this book.

Candidate prebiotics are reported to be particularly suited to the growth and activities of the bifidobacteria and lactobacilli (Rowland and Tanaka, 1993; Fuller and Gibson,

Table 1.4 Some candidate prebiotic compounds

\begin{tabular}{|c|c|c|}
\hline Prebiotic & Production method & Reference \\
\hline $\begin{array}{l}\text { Inulin } \\
\text { [Fructooligosaccharide } \\
\text { (FOS)] }\end{array}$ & $\begin{array}{l}\text { Hot water extraction from } \\
\text { chicory root (followed by } \\
\text { enzymatic hydrolysis) or } \\
\text { polymerization of fructose } \\
\text { monomers }\end{array}$ & Bornet et al., 2002 \\
\hline $\begin{array}{l}\text { Galactooligosaccharide } \\
\text { (GOS) }\end{array}$ & $\begin{array}{l}\text { Enzymatic lactose } \\
\text { transgalactosylation }\end{array}$ & Teuri and Korpel, 1998 \\
\hline $\begin{array}{l}\text { Xylooligosaccharide } \\
\text { (XOS) }\end{array}$ & $\begin{array}{l}\text { Enzymatic hydrolysis of } \\
\text { plant xylans }\end{array}$ & Imaizumi et al., 1991 \\
\hline $\begin{array}{l}\text { Isomaltooligosacchairde } \\
\text { (IMO) }\end{array}$ & $\begin{array}{l}\text { Transglucosylation of } \\
\text { liquefied starch }\end{array}$ & Morgan et al., 1992 \\
\hline Lactulose & Isomerization of lactose & $\begin{array}{l}\text { Salminen and Salminen, } \\
1997\end{array}$ \\
\hline
\end{tabular}


Table 1.5 Natural occurrence of fructooligosaccharides (Data sourced from Mitsuoka et al., 1987; Roberfroid et al., 1993; Modler, 1994)

\begin{tabular}{llll}
\hline Source & Scientific name & $\begin{array}{l}\text { Fructose } \\
\text { units }\end{array}$ & $\begin{array}{l}\text { Fructooligosaccharides (\%) } \\
\text { in fresh material }\end{array}$ \\
\hline Banana & Musa spp. & 2 & $0.3-0.7$ \\
Rye & Secale cereale & 2 & $0.5-1.0$ \\
Leek & Allium ampeloprasmus & $n^{a}$ & $2.0-10.0$ \\
Wheat & Triticum asetivum & $n$ & $0.8-4.0$ \\
Garlic & Allium sativum & $n$ & $1.0-16.0$ \\
Chicory roots & Cichorium intybus & $n$ & $15.0-24.0$ \\
Asparagus shoot & Asparagus officinalis & $2-4$ & $2.0-3.0$ \\
Jerusalem artichoke & Heliantus tuberosus & 2 & $16.0-22.0$ \\
Globe artichoke & Cynara scolymus & 2 & $3.0-10.0$ \\
Onions & Allium cepa & $2-4$ & $1.1-7.5$ \\
Salisfy & Scorzonera hispanica & $n$ & $4.0-11.0$ \\
Dandelion & Taraxacum officinale & $n$ & $12.0-15.0$ \\
Dahlia & - & $n$ & 13.0 \\
Burdock & - & $2-4$ & 3.6 \\
\hline
\end{tabular}

${ }^{a} n$ is either $>4$ or number of individual fructose units not described as yet.

1998; Bouhnik et al., 1999). These are classed as beneficial microorganisms because species within these groups have been reported to exert therapeutic and prophylactic influences on the health of infants and adults (Goldin and Gorbach, 1992; Salminen et al., 1998a). The high incidence of Bifidobacterium spp. in breast-fed babies for example may be instrumental in protection against childhood diseases and prevent the colonisation of transient pathogens (Fuller, 1991). Likewise, reduced levels of bifidobacteria may, at least partly, explain increased susceptibility to disorders in the elderly (Mitsuoka, 1990; Rowland and Tanaka, 1993; Gibson et al., 1995; Buddington et al., 1996). A potential correlation therefore exists with reduced pathogen resistance, decreased numbers of bifidobacteria in the elderly and the production of natural resistance factors. In essence, the natural gut flora may be compromised through reduced bifidobacterial numbers and have a reduced ability to deal with pathogens. If prebiotics are used to increase bifidobacteria or lactobacilli towards being the numerically predominant genus in the colon, an improved colonisation resistance ought to result, but has not yet been proven.

By definition, a prebiotic must stimulate the growth of a limited number of bacteria and thus will lead to a change in the overall microbial balance in the colon. Static batch culture fermentations with human faecal bacteria have shown that fructooligosaccharides (FOS), galactooligosaccharides (GOS), xylooligosaccharides (XOS), isomaltooligosaccharides (IMO) and lactulose alter the microflora, increasing the level of bifidobacteria and/or lactobacilli and in some cases causing clostridia and bacteroides to decline (Rycroft et al., 2001). Another in vitro study, using a more complex model for fermentation in the colon, found that inulin increased lactobacilli and to a lesser extent bifidobacteria, in simulations of proximal regions of the model (McBain and Macfarlane, 2001). This study also investigated GOS in the same way and found that adding it to the model increased bifidobacteria and lactobacilli in regions of the model representing the 
proximal and transverse colon. Similar results have also been recorded in feeding studies on rodents. When inulin was given in the diet of mice caecal bacteria increased as did the production of SCFA, causing a reduction in $\mathrm{pH}$ (Apajalahti et al., 2002). Molecular analysis of caecal contents by GC profiling showed large changes in populations. Sequencing showed that inulin increased bifidobacteria and decreased the less desirable clostridia and desulfovibrios as well as causing changes in the levels of unidentified species. In another study, resistant starch was administered to human flora associated rats to assess its prebiotic effects (Silvi et al., 1999). In this case, lactic acid bacteria increased and enterobacteria decreased. Modulation of the flora can also be seen in human feeding studies. GOS and FOS have been shown to increase faecal bifidobacteria (Ito et al., 1990; Bouhnik et al., 1999) This effect has been shown to be both dose-dependent and related to the initial level of bifidobacteria, with individuals with the lowest starting populations showing the greatest increase, also reflecting in vitro observations by Rycroft et al. (2001).

Three oligosaccharides are available in usable quantities in Europe and seem to have proven efficacy. These are fructooligosaccharides (including inulin), trans-galactooligosaccharides and lactulose. Molecular based methodologies in human trials to confirm the prebiotic effect of FOS and lactulose (Tuohy et al., 2001a, 2002). The former has also been seen to be a highly effective prebiotic when incorporated into a biscuit product at 8 g per day (Tuohy et al., 2001b). Other prebiotics, as mentioned above, are widely used in Japan. Some may have more desirable attributes than the currently recognised European forms and this is currently under evaluation. Moreover, the use of 'glycobiology' offers the deliberate manufacture of multi-functional prebiotics. This could include forms that have anti-adhesive capacities against common food borne pathogens, types that persist to the distal bowel (the main site of colonic disorder), carbohydrates which attenuate the virulent properties of certain microorganisms and prebiotics that target individual species, not genera, of gut bacteria (Gibson et al., 2000).

\subsubsection{Evaluating Prebiotic Functionality}

A variety of model systems have been developed to investigate colonic fermentation of prebiotics (Rumney and Rowland, 1992; Conway, 1995; Rycroft et al., 1999). Screening usually starts by looking at the relative fermentability of prebiotics with in vitro static batch culture fermenters. In its simplest form, the effect is investigated with selected pure cultures of gut bacteria in anaerobic Hungate tubes sealed under nitrogen. This is advantageous because results can be generated quickly and become especially useful, e.g. in some cases when only low amounts of oligosaccharides are available. However, this method does not identify true selectivity of a substrate. A modification is the use of defined mixed- or co-cultures as inocula (Rycroft et al., 1999). This may introduce competition between microbes but still does not fully represent the complex interactions present in the human large intestine. Further modifications have thus used faecal suspensions to increase diversity, larger vessels and volumes, stirred conditions with $\mathrm{pH}$ and temperature control allowing more comparative determinations to be made on fermentability. The prebiotic effect is determined at intervals by removing samples and assessing growth through cultural microbiological techniques or molecular based methods. However, these are all closed systems in which substrate availability soon 
becomes the limiting factor, and there is an inevitable build up of acid and metabolites that can affect carbohydrate utilisation.

Conversely, parameters in continuous cultures (chemostats) such as varying dilution rate and $\mathrm{pH}$ can be optimised to conditions, physiologically more similar to events that occur in the large gut (Gibson and Wang, 1994a). There is a continuous input of growth media at one end whilst spent culture plus bacteria is steadily removed at another end, thus enabling continual biomass production and eventually reaching steady state. At steady state, equilibrium is reached, growth rate is equal to dilution rate and this enables the composition of a diverse microflora community to be maintained whilst reproducible measurements can be made. In their simplest form, continuous culture systems usually consist of one reaction vessel, but variations occur. One study to examine the prebiotic effect of oligofructose (FOS) used both single- and a three-stage continuous culture models of the human large intestine (Gibson and Wang, 1994a,b). The multiple-stage system was set up with vessels in succession; the first, relatively nutrient-rich, acidic $\mathrm{pH}$ and faster transit (due to a small operating volume) than the third with a more neutral $\mathrm{pH}$ and comparatively less substrate, thus mimicking the proximal and the distal colonic environments, respectively. Conditions for the transverse colon were represented in vessel two. Parameters and events in the three-stage gut model have been validated against the colonic contents of sudden death victims (Macfarlane et al., 1998). Species composition in the three compartments representing different regions of the human large intestine, population levels and chemical measurements correlated well with the in vivo samples, proving a useful model for studying nutritional effects on intestinal ecology and physiology. Another model attempted to study digestive events from the jejunum to the distal regions of the colon has been developed, consisting of five vessels sequentially fed with growth media (Molly et al., 1993). Semi-continuous variations have also been used when medium is added and spent culture removed at timed intervals (Rumney and Rowland, 1992; Miller and Wolin, 1981). Although these models are designed and controlled to represent metabolic events that take place in the lower gut environments, limitations arise, especially from the inability to study contributions from biofilm communities and the absence of a physiological absorptive mechanism.

These can be overcome by using animal models, like rats and mice, but large differences do occur in microflora between the rodent's intestinal system and humans. The use of germ-free (gnotobiotic) rats associated with human faecal flora, known as human flora associated rats may further simulate, but still not fully represent, the human intestinal physiology. The use of human volunteers in properly controlled (dose, duration, diet, blinded) studies is the ultimate test for prebiotic functionality, however, analysis is carried out on faecal material and this may poorly represent events in proximal regions. It has been suggested that a consolidation of all these approaches, systematically performed, should clearly indicate the potential of candidate prebiotics to be of beneficial value (Rycroft et al., 1999).

\subsection{Health Outcomes Associated with Prebiotic Intake}

The health outcomes of prebiotic intake can be similar to those described for probiotics if the selectively stimulated bacteria possess probiotic properties. In addition, there are 
benefits of dietary prebiotic supplementation that stand alone from effects attributable to an increase in the numbers of lactic acid bacteria, and are instead due to a switch in the metabolism of these organisms.

\subsubsection{Acute Gastroenteritis}

Acute gastroenteritis is something that probably affects everyone at one time or another. Usually it involves the ingestion of food or water contaminated with pathogenic microorganisms and/or their toxins (Hui et al., 1994). The economic costs and medical aspects are therefore huge, with food safety incidence still increasing in most civilisations. Typical causative agents include shigellae, salmonellae, Yersinia enterocolitica, Campylobacter jejuni, E. coli, Vibrio cholera and Clostridium perfringens. Pathogens may either, colonise and grow within the gastrointestinal tract and then invade host tissue, or they may secrete toxins contaminating food prior to its ingestion. Such toxins disrupt function of the intestinal mucosa, causing nausea, vomiting and diarrhoea (Hui et al., 1994). The principal human intestinal bacterial pathogens can be characterised according to the virulence factors that enable them to overcome host defences. These include invasion which enables bacterial multiplication within enterocytes or colonocytes, for example E. coli, Shigella spp., salmonellae and yersinae. Cytotoxic bacteria which include enteropathogenic and enterohaemorrhagic strains of E. coli as well as some shigellae are able to produce substances which can directly cause cell injury. Toxigenic bacteria such as $V$. cholerae and some shigellae are capable of producing enterotoxins, which affect salt and water secretion in the host. Lastly, enteroaggregative E. coli have the ability to tightly adhere to the colonic mucosa. Such mechanisms enable potentially pathogenic bacteria to establish infections in the gastrointestinal tract, evade the immune system and surmount colonisation resistance afforded by the indigenous gut microflora.

The gut microflora and the mucosa itself act as a barrier against invasion by potentially pathogens. Bifidobacteria and lactobacilli may inhibit pathogens like E. coli, Campylobacter and Salmonella spp. (Gibson and Wang, 1994b). The lactic microflora of the human gastrointestinal tract is thought to play a significant role in improved colonisation resistance (Gibson et al., 1997). There are a number of possible mechanisms in operation:

- metabolic end products such as acids excreted by these microorganisms may lower the gut $\mathrm{pH}$, in a microniche, to levels below those at which pathogens are able effectively compete;

- competitive effects from occupation of normal colonisation sites;

- direct antagonism through natural antimicrobial excretion;

- competition for nutrients.

The possibility exists therefore, that increased levels of beneficial bacteria in the large gut may, along with other factors such as immune status, offer improved protection. This is in a similar manner to probiotics, but may well be more efficacious given the comparative survivability issues.

The idea of combining prebiotic properties with anti-adhesive activities is currently under investigation. This would add major functionality to the approach of altering gut pathogenesis. Many intestinal pathogens utilise monosaccharides or short 
oligosaccharide sequences as receptors and knowledge of these receptor sites has relevance for biologically enhanced prebiotics. Binding of pathogens to these receptors is the first step in the colonisation process (Finlay and Falkow, 1989; Karlsson, 1989). There are currently several pharmaceutical preparations based upon such oligosaccharides in clinical trials. These agents are multivalent derivatives of the sugars and act as 'blocking factors', dislodging the adherent pathogen (Heerze et al., 1994; Jayaraman et al., 1997). There is much potential for developing prebiotics, which incorporate such a receptor monosaccharide or oligosaccharide sequence. These molecules should have enough anti-adhesive activity to inhibit binding of low levels of pathogens.

The prebiotic concept may be extrapolated further by considering an attenuation of virulence in certain food-borne pathogens. For example, the plant derived carbohydrate cellobiose is able to repress pathogenicity in Listeria monocytogenes through down regulation of its virulence factors (Park and Kroll, 1993). As such, this organism is avirulent in its natural habitat of soil, where it is exposed to rotting vegetation and therefore cellobiose. In the human body, an absence of cellobiose may allow the virulence factors to be expressed, and it is possible that further incorporation of this disaccharide to foods susceptible to Listeria contamination could reduce this virulence.

\subsubsection{Reduction of Cancer Risk}

Genotoxic enzyme activity has been seen to reduce on the administration of prebiotics. An early study on feeding GOS to humans resulted in a decrease in nitroreductase (a metabolic activator or mutagenic/carcinogenic substances) and also decreased levels of indole and isovaleric acid (produced as products of proteolysis and deamination and markers of putrefaction) (Ito et al., 1990). When a model system of the human gut was used to investigate the effect of GOS on genotoxic enzymes it was found that $\beta$-glucosidase, $\beta$-glucuronidase and arylsulphatase were strongly inhibited but azoand nitroreductase were stimulated (McBain and Macfarlane, 2001). As these effects occurred rapidly on the addition of GOS to the system, changes attributable to population levels can be ruled out and it is more feasible that direct inhibition by GOS or the production of repressors or deactivators by bacteria was responsible. However, increasing the proportion of bifidobacteria and lactobacilli at the expense of bacteroides and clostridia may also decrease genotoxic enzyme production, as the former produce lower levels of such enzymes than the latter (Burns and Rowland, 2000).

Another study looked at the effects of resistant starch administration to human-flora associated rats (Silvi et al., 1999). Although $\beta$-glucosidase increased, $\beta$-glucuronidase and ammonia levels decreased. A further observation important to the reduction of cancer was a high level of caecal butyrate. Not only is butyrate the major source of energy for colonocytes and helps maintain a healthy epithelium (Topping and Clifton, 2001), it can also play an important role in preventing cancer. Several cellular processes are affected by butyrate, largely by interaction with DNA and its surrounding proteins (Kruh, 1982). These processes include induction of apoptosis, a process which is deactivated in cancer cells which would normally lead to their elimination and an increase in immunogenicity of cancer cells due to an increase in expression of cell surface proteins (Bornet et al., 2002). However, it should be pointed out that the usual target bacteria for prebiotic use 
(bifidobacteria, lactobacilli) are not butyrate producers. Hence, there could be rationale for fortifying other gut flora components (e.g. eubacteria).

\subsubsection{Mineral Absorption}

Uptake of calcium and magnesium is crucial for bone structure and increasing absorption can prevent conditions such as osteoporosis. Chonan et al. (2001) have shown that adding GOS to the diet of rats can increase calcium and magnesium absorption. The mechanism for this is unclear but in this case the presence of a colonic flora is required for GOS to have this effect, though the authors acknowledged that microbial mediated and nonmicrobial mediated mechanisms probably exist. FOS can also affect mineral absorption and in human studies $15 \mathrm{~g}$ per day oligofructose or $40 \mathrm{~g}$ per day inulin increased the apparent calcium absorption (Roberfroid, 2002). Magnesium absorption has also been shown to increase when ingesting FOS (Bornet et al., 2002).

\subsubsection{Lipid Regulation}

Prebiotics may also have an effect on lipid regulation. Although the mechanism is currently unknown, studies have shown positive results and mechanistic hypotheses have been developed. A study on diabetic rats found that when XOS replaced simple carbohydrates in the diet, the serum cholesterol and triglyceride increases observed in diabetes were reduced and liver triglycerides increased to a comparable level seen in healthy rats (Imaizumi et al., 1991). Other studies have examined FOS, which was also found to reduce blood lipids (Bornet et al., 2002; Roberfroid, 2002). This was thought to be due to an inhibition of lipogenic enzymes in the liver, which may be a result of the action of propionate produced from the fermentation of prebiotics by gut bacteria (Wolever et al., 1991). Whilst prebiotics can be of use in correcting hyperlipidaemia brought about by diabetes and other conditions, decreases in lipids have not been observed in healthy subjects (Bornet et al., 2002), which is a useful safety feature as misuse or overdose does not seem to have negative effects.

\subsubsection{Development of New Prebiotics}

As our understanding of the interactions of the gut flora with its host improves, more prebiotics are being designed with specific health outcomes in mind, and from different materials. Native polymers or those that have been made into oligosaccharides that may have prebiotic effects include dextran (Olano-Martin et al., 2000), bacterial exopolysaccharide (Korakli et al., 2002), chitin and chitosan (Lee et al., 2002) and components of the dietary fibre found in cereal grains (Charalampopoulos et al., 2002). These materials are all abundant and inexpensive; another important quality when developing potential prebiotics.

\subsection{Synbiotics}

Synbiotics can be described as 'a mixture of probiotics and prebiotics that beneficially affects the host by improving the survival and implantation of live microbial dietary 
supplements in the gastrointestinal tract, by selectively stimulating the growth and/or activating the metabolism of one or a limited number of health promoting bacteria, and thus improving host welfare' (Gibson and Roberfroid, 1995). By combining the probiotic and prebiotic strategies previously described, additive or synergistic effects may be observed. There are numerous mechanisms by which this may occur. Increased survival of probiotic bacteria and hence shelf life in consumer products as a result of prebiotic addition would lead to an increased ingestion of viable cells (Shin et al., 2000). Higher probiotic numbers may also be achieved by simultaneous feeding with a prebiotic which can be competitively utilised by the probiotic (Holzapfel and Schillinger, 2002). In addition, the presence of a prebiotic may not only stimulate the growth or activity of the fed probiotic strain but also selected indigenous bacteria in the colon that are considered beneficial (Roberfroid, 1998). Furthermore, it may be possible to target a synbiotic product to two different regions of the gastrointestinal tract, for example the small and large intestine (Holzapfel and Schillinger, 2002).

In a study on weanling pigs, Bomba et al. (2002) found that when FOS was given at the same time as the probiotic Lactobacillus paracasei there was a significantly greater increase in lactobacilli and bifidobacteria than was observed with the probiotic alone.

Other studies have shown an increased persistence of probiotics in synbiotic preparations both in terms of the location in the colon (Rastall and Maitin, 2002) and how long the effects can be seen following cessation of taking the product (Roberfroid, 1998), the latter being a possible indicator of better implantation of the probiotic strain into the indigenous flora or a more general increase in indigenous bifidobacteria caused by the prebiotic.

Colon cancer has been studied as a situation where synbiotics could be of benefit. Most studies have been carried out in rats and looked at the reduction in number of aberrant crypt foci (cancer precursors) in rats treated with azoxymethane (a tumour promoter). Gallaher and Khil (1999) found that FOS and bifidobacteria had no effect when administered alone but as a synbiotic five out of six subjects had decreased aberrant crypt foci. Another study has shown that whilst a mixture of short and long chain FOS can decrease the number of adenomas and malignant cancers, a mixture of Lactobacillus reuteri GG and Bifidobacterium lactis Bb12 only had an effect in reducing numbers of malignant tumours. The results were improved with the pro and prebiotics combined but this time the effects were seen to be additive and not synergistic (Fermia et al., 2002).

Immune modulation may also be more effective with synbiotics, and may be an example whereby different components of the synbiotic act at different sites. The same combination of pro and prebiotics were as used by Fermia et al. (2002) and immune parameters measured. The results showed that peripheral blood mononuclear cells were specifically affected by probiotics and prebiotics but in some immune compartments a greater effect was shown by the synbiotic (Roller et al., 2004).

\section{References}

Alander, M., Matto, J., Kniefel, W., Johansson, M., Kogler, B., Crittenden, R., Mattila-Sandholm, T. and Saarela, M. (2001) Effect of galacto-oligosaccharide suplementation on human faecal microflora and on survival and persistance of Bifidobacterium lactis Bb-12 in the gastrointestinal tract. International Dairy Journal, 11, 817-825. 
Alvarez-Olmos, M. I. and Oberhelman, R. A. (2001) Probiotic agents and infectious diseases: a modern perspective on a traditional therapy. Clinical Infectious Diseases, 32, $1567-1576$.

Anderssen, E. L., Diep, D. B., Nes, I. F., Eijsink, V. G. H. and Nissen-Meyer, J. (1998) Antagonistic activity of Lactobacillus plantarum C11: two new two-peptide bacteriocins, plantaricins EFand JK, and the induction factor plantaricin A. Applied and Environmental Microbiology, 64, 2269-2272.

Apajalahti, J. H., Kettunen, H., Kettunen, A., Holben, W. E., Nurminen, P. H., Rautonen, N. and Mutanen, M. (2002) Culture-independent microbial community analysis reveals that inulin in the diet primarily affects previously unknown bacteria in the mouse cecum. Applied and Environmental Microbiology, 68, 4986-4995.

Bengmark, S. (1998) Ecological control of the gastrointestinal tract. The role of probiotic flora. Gut, 42, 2-7.

Beritzoglou, E. (1997) The intestinal flora during the first weeks of life. Anaerobe, 3, 173-177.

Bingham, S. A., Pett, S. and Day, K. C. (1990) NSP intake of a representative sample of British adults. Journal of Human Nutrition and Diet, 3, 339-344.

Bomba, A., Nemcova, R., Gancarcikova, S., Herich, R., Guba, P. and Mudronova, D. (2002) Improvement of the probiotic effect of microorganisms by their combination with maltodextrins, fructo-oligosaccharides and polyunsaturated fatty acids. British Journal of Nutrition, 88, 95S-99S.

Bornet, F. R. J., Brouns, F., Tashiro, Y. and Duviller, V. (2002) Nutritional aspect of short-chain fructooligosaccharides: natural occurrence, chemistry, physiology and health implications. Digestive and Liver Disease, 34, S111-S120.

Bouhnik, Y., Vahedi, K., Achour, L., Attar, A., Salfati, J., Pochart, P., Marteau, P., Flourie, B., Bornet, F. and Rambaud, J.-C. (1999) Short-chain fructo-oligosaccharide administration dose-dependently increases faecal bifidobactera in humans. Journal of Nutrition, 129, 113-116.

Bruno, F. A. and Shah, N. P. (2002) Inhibition of pathogenic and putrefactive microorganisms by Bifidobacterium sp. Milchwissenschaft, 57, 617-621.

Burns, A. J. and Rowland, I. R. (2000) Anti-carcinogenicity of probiotics and prebiotics. Current Issues in Intestinal Microbiology, 1, 13-24.

Bucke, C. and Rastall, R. A. (1990) Synthesising sugars by enzymes in reverse. Chemistry Britain, 26, 675-678.

Buddington, R. K., Williams, C. H., Chen, S. and Witherly, S. A. (1996) Dietary supplement of neosugar alters the faecal flora and decreases activities of some reductive enzymes in human subjects. American Journal of Clinical Nutration, 63, 709-716.

Burns, A. J. and Rowland, I. R. (2000) Anti-carcinogenicity of probiotics and prebiotics. Current Issues in Intestinal Microbiology, 1, 13-24.

Chadwick, V. S. and Anderson, R. P. (1995) The role of intestinal bacteria in etiology and maintenance of inflammatory bowel diseases. In: Human Colonic Bacteria: Role in Nutrition, Physiology and Pathology. G. R. Gibson and G. T. Macfarlane (Eds). CRC Press, Boca Raton, FL, pp. 227-256.

Charalampopoulos, D., Wang, R., Pandiella, S. S. and Webb, C. (2002) Application of cereals and cereal components in functional foods: a review. International Journal of Food Microbiology, 79, $131-141$.

Chonan, O., Takahashi, R. and Watanuki, M. (2001) Role and activity of gastrointestinal microflora in absorption of calcium and magnesuim in rats fed b1-4 linked galactooligosaccarides. Bioscience, Biotechnology and Biochemistry, 65, 1872-1875.

Conway, P. L. (1995) Microbial ecology of the human large intestine. In: Human Colonic Bacteria: Role in Nutrition, Physiology and Pathology. G. R. Gibson and G. T. Macfarlane (Eds). CRC Press, Boca Raton, FL, pp. 1-24.

Cross, M. (2002) Microbes versus microbes: immune signals generated by probiotic lactobacilli and their role in protection against microbial pathogens. FEMS Immunology and Medical Microbiology, 34, 245-253.

Cummings, J. H. (1981) Cellulose and the human gut, Gut, 25, 805-810. 
Cummings, J. H. (1995) Short chain fatty acids. In: Human Colonic Bacteria: Role in Nutrition, Physiology and Pathology. G. R. Gibson and G. T. Macfarlane (Eds). CRC Press, Boca Raton, FL, pp. 101-130.

Cummings, J. H. and Macfarlane, G. T. (1991) The control and consequences of bacterial fermentation in the human colon: a review. Journal of Applied Bacteriology, 70, 443-459.

Duerden, B. I., Wade, W. G., Brazier, J. S., Eley, A., Wren, B. and Hudson, M. J. (Eds) (1995) Ecology and epidemiology of Clostridium difficile. In: Medical and Dental Aspects of Anaerobes. Science Reviews, Middlesex, pp. 153-248.

Dunne, C. (2001) Adaptation of bacteria to the intestinal niche: probiotics and gut disorder. Inflammatory Bowel Disease, 7, 136-145.

Ellegärd, L., Andersson, H. and Bosaeus, I. (1997) Inulin and oligofructose do not influence the absorption of cholesterol, or the excretion of cholesterol, $\mathrm{Ca}, \mathrm{Mg}, \mathrm{Zn}, \mathrm{Fe}$ or bile acids but increases energy excretion in ileostomy subjects. European Journal of Clinical Nutrition, 51, 1-5.

Engelhardt, W., Busche, R., Gros, G. and Rechkemmer, G. (1991) Absorption of short-chain fatty acids: mechanisms and regional differences in the large intestine. In: Short-chain Fatty Acids: Metabolism and Clinical Importance. J. H. Cummings, J. L. Rombeau and T. Sakata (Eds). Ross Laboratories Press, Columbus, pp. 60-62.

Englyst, H. N. and Cummings, J. H. (1986) Digestion of the carbohydrates of banana (Musa paradisiaca sapientum) in the human small intestine. American Journal of Clinical Nutrition, 44, 42-50.

Englyst, H. N. and Cummings, J. H. (1987) Digestion of polysaccharides of potato in the small intestine of man. American Journal of Clinical Nutrition, 45, 423-431.

Englyst, H. N. and Macfarlane, G. T. (1986) Breakdown of resistant and readily digestible starch by human gut bacteria. Journal of Science and Food Agriculture, 37, 699-706.

Fermia, A. P., Luceri, C., Dorola, P., Giannini, A., Biggeri, A., Salvadori, M., Clune, Y., Collins, K. J., Paglierani, M. and Caderni, G. (2002) Antitumorigenic activity of the prebiotic inulin enriched with oligofructose in combination with the prebiotics Lactobacillus rhamnosus and Bifidobacterium lactis on azoxymethane-induced colon carcinogenesis in rats. Carcinogenesis, 23, 1953 1960.

Finlay, B. B. and Falkow, S. (1989) Common themes in microbial pathogenicity. Microbiological Reviews, 53, 210-230.

Fujiwara, S., Seto, Y., Kimura, A. and Hashiba, H. (2001) Intestinal transit of an orally administered strptomycin-rifampcin-resistant variant of Bifidobacterium longum 2928: its long-term survival and effect on the intestinal microflora and metabolism. Journal of Applied Microbiology, 29, 43-52.

Fuller, R. (1989) Probiotics in man and animals. Journal of Applied Bacteriology, 66, 365-378.

Fuller, R. (1991) Factors affecting the composition of the intestinal microflora of the human infant. In: Nutritional Needs of the Six to Twelve Month Old Infant. W. C. Heird (Ed.). Carnation Nutrition Education Glendale / Raven Press Ltd, New York, Series 2, pp. 121-130.

Fuller, R. and Gibson, G. R. (1998) Probiotics and prebiotics: microflora management for improved gut health. Clincinal Microbiology and Infection, 4, 477-480.

Gallaher, D. D. and Khil, J. (1999) The effect of synbiotics on colon carcinogenesis in rats. Journal of Nutrition, 129 (Suppl.), 1483S-1487S.

Gerasimov, S. V. (2004) Probiotic prophylaxis in paediatric recurrent urinary tract infections. Clinical Paediatrics, 43, 95-98.

Gibson, G. R. (1998) Dietary modulation of the human gut microflora using prebiotics. British Journal of Nutrition, 80, S209-S212.

Gibson, G. R. and Collins, M. D. (1999) Concept of balanced colonic microbiota, prebiotics and synbiotics. In: Probiotics, Other Nutritional Factors and Intestinal Microflora. L. A. Hanson and R. H. Yolken (Eds). Nestle Nutrition Workshop Series, vol. 42. Raven Publishers, Philadelphia, pp. 139-153.

Gibson, G. R. and Roberfroid, M. B. (1995) Dietary modulation of the human colonic microbiota: introducing the concept of prebiotics. Journal of Nutrition, 125, 1401-1412.

Gibson, G. R. and Wang, X. (1994a) Enrichment of bifidobacteria from human gut contents by oligofructose using continuous culture. FEMS Microbiological Letters, 118, 121-128. 
Gibson, G. R. and Wang, X. (1994b) Regulatory effects of bifidobacteria on the growth of other colonic bacteria. Journal of Applied Bacteriology, 77, 412-420.

Gibson, G. R., Macfarlane, S. and Cummings, J. H. (1990) The fermentability of polysaccharides by mixed human faecal bacteria in relation to their suitability as bulk-forming laxatives. Letters in Applied Microbiology, 11, 251-254.

Gibson, G. R., Beatty, E. R., Wang, X. and Cummings, J. H. (1995) Selective stimulation of bifidobacteria in the human colon by oligofructose and inulin. Gastroenterology, 108, 975-982.

Gibson, G. R., Saavedra, J. M., Macfarlane, S. and Macfarlane, G. T. (1997) Probiotics and intestinal infections. In: Probiotics 2: Applications and Practical Aspects. R. Fuller (Ed.). Chapman and Hall, London, pp. 10-39.

Gibson, G. R., Rastall, R. A. and Roberfroid, M. B. (1999) Prebiotics. In: Colonic Microbiota: Nutrition and Health. G. R. Gibson and M. B. Roberfroid (Eds). Kluwer Academic Press, Dordrecht, pp. 101-124.

Gibson, G. R., Berry Ottaway, P. and Rastall, R. A. (2000) Prebiotics: New Developments in Functional Foods. Chandos Publishing Limited, Oxford.

Gibson, G. R., Probert, H. M., van Loo, J. A. E., Rastall, R. A. and Roberfroid, M. B. (2004) Dietary modulation of the human colonic microbiota: Updating the concept of prebiotics. Nutrition Research Reviews, 17, 259-275.

Gionchetti, P., Rizzello, F., Venturi, A. and Campieri, M. (2000) Probiotics in infective diarrhoea and inflammatory bowel diseases. Journal of Gastroenterology and Hepatology, 15, 489-493.

Goldin, B. R. and Gorbach, S. L. (1992) Probiotics for humans. In: Probiotics. The Scientific Basis. Fuller R. (Ed.). Chapman and Hall, London, pp. 355-376.

Gorbach, S. L. (2002) Probiotics in the third millennium. Digestive and Liver Disease, 34, S2-S7.

Gronlund, M. M., Lehtonen, O. P., Eerola, E. and Kero, P. (1999) Faecal microflora in healthy infants born by different methods of delivery: permanent changes in intestinal flora after Cesarean delivery. Journal of Paediatric Gastroenterology and Nutrition, 28, 19-25.

Havenaar, R. and Huis in't Veld, J. H. J. (1992) Probiotics: a general view. In: The Lactic Acid Bacteria. Vol 1. The Lactic Acid Bacteria in Health and Disease. B. J. B Wood (Ed.). Elsevier Applied Science, Barking, pp. 151-170.

Havenaar R., Ten Brink, B. and Huis in't Veld, J. H. J. (1992) In: Probiotics. The Scientific Basis. R. Fuller (Ed.). Chapman and Hall, London, pp. 209-224.

Heerze, L. D., Kelm, M. A. and Talbot, J. A. (1994) Oligosaccharide sequences attached to an inert support (SYNSORB) as potential therapy for antibiotic-associated diarrhoea and pseudomembranous colitis. Journal of Infectious Diseases, 169, 1291-1296.

Holzapfel, W. H. and Schillinger, U. (2002) Introduction to pre- and probiotics. Food Research International, 35, 109-116.

Hudson, M. J. and Marsh, P. D. (1995) Carbohydrate metabolism in the colon. In: Human Colonic Bacteria: Role in Nutrition, Physiology and Pathology. G. R. Gibson and G. T. Macfarlane (Eds). CRC Press, Boca Raton, FL, pp. 61-73.

Hui, Y. H., Gorham, J. R., Murrell, K. D. and Cliver, D. O. (Eds) (1994) Foodborne diseases Handbook-Diseases Caused by Bacteria. Marcel Dekker Inc., New York.

Imaizumi, K., Nakatsu, Y., Sato, M., Sedarnawati, Y. and Sugano, M. (1991) Effects of xylooligosaccharides on blood glucose, serum and liver lipids and caecum short-chain fatty acids in diabetic rats. Agriculture Biology and Biochemistry, 55, 199-205.

Ito, M., Deguchi, Y., Miyamori, A., Matsumoto, K., Kikuchi, H., Matsumoto, K., Kobayashi, Y., Yajima, T. and Kan, T. (1990) Effects of administration of galactooligosaccharide on the human feacal microflora, stool weight and abdominal sensation. Microbial Ecology in Health and Disease, 3, 285-292.

Jacobsen, C. N., Nielsen, V. R., Hayford, A. E., Moller, P. L., Michaelson, K. F., Paeregaard, A., Sandstrom, B., Tvede, M. and Jakobsen, M. (1999) Screening of the probiotic activities of fortyseven strains of Lactobacillus spp. by in vitro techniques and evaluation of the colonization ability of five selected strains in humans. Applied and Environmental Microbiology, 65, 4949-4956.

Jayaraman, N., Nepogodiev, S. A. and Stoddart, J. F. (1997) Synthetic carbohydrate-containing dendimers. Chemistry in Europe Journal, 3, 1193-1199. 
Kailasapathy, K. and Chin, J. (2000) Survival and therapeutic potential of probiotic organisms with reference to Lactobacillus acidophilus and Bifidobacterium spp. Immunology and Cell Biology, 78, 80-88.

Karlsson, K.-A. (1989) Animal glycosphingolipids as membrane attachment sites for bacteria. Annual Review of Biochemistry, 58, 309-50.

Klijn, N., Weerkamp, A. H. and de Vos, W. M. (1995) Genetic marking of Lactococcus lactis shows its survival in the human gastrointestinal tract. Applied and Environmental Microbiology, 61, 2771-2774.

Korakli, M., Ganzle, M. G. and Vogel, R. F. (2002) Metabolism by Bifidobacteria and lactic acid bacteria of polysaccharides from wheat, rye and exopolysaccharides produced by Lactobacillus sanfranciencis. Journal of Applied Microbiology, 92, 958-965.

Kruh, J. (1982) Effects of sodium butyrate, a new pharmacological agent on cells in culture. Molecular and Cellular Biochemistry, 42, 65-82.

Kunz, C. and Rudloff, S. (1993) Biological functions of oligosaccharides in human milk. Acta Paediatric, 82, 903-912.

Langendijk, P. S., Schut, F., Jansen, G. J., Raangs, G. C., Kamphuis, G. R., Wilkinson, M. H. F. and Welling, G. W. (1995) Quantitative fluorescence in situ hybridisation of Bifidobacterium spp. with genus-specific 16S rRNA-targeted probes and its application in faecal samples. Applied and Environmental Microbiology, 61, 3069-3075.

Levitt, M. D., Gibson, G. R. and Christl, S. U. (1995) Gas metabolism in the large intestine. In: Human Colonic Bacteria: Role in Nutrition, Physiology and Pathology. G. R. Gibson and G. T. Macfarlane (Eds). CRC Press, Boca Raton, FL, pp. 131-153.

Lewis, B. A., Hall, M. B. and Van Soest, P. J. (2001) Interaction between human gut bacteria and dietary fiber substrates. In: CRC Handbook of Dietary Fiber in Human Nutrition, 3rd Edition. G. A. Spiller (Ed.). CRC Press, Boca Raton, FL, pp. 271-276.

Macfarlane, G. T. and Cummings, J. H. (1991) The colonic flora, fermentation and large bowel digestive function. In: The Large Intestine: Physiology, Pathophysiology and Disease. S. F. Phillips, J. H. Pemberton and R. G. Shorter (Eds). Raven Press, New York, pp. 51-88.

Macfarlane, G. T. and Gibson, G. R. (1994) Metabolic activities of the normal colonic flora. In: Human Health: The Contribution of Microorganisms. S. A. W. Gibson (Ed.). Springer, London, pp. 17-52.

Macfarlane, G. T. and Macfarlane, S. (1995) Proteolysis and amino acid fermentation. In: Human Colonic Bacteria: Role in Nutrition, Physiology and Pathology. G. R. Gibson and G. T. Macfarlane (Eds). CRC Press, Boca Raton, FL, pp. 75-100.

Macfarlane, G. T. and Macfarlane, S. (1997) Human colonic microbiota: ecology, physiology and metabolic potential of intestinal bacteria. Scandinowian Journal of Gastroenterology, 32 (Suppl. 222), 3-9.

Macfarlane, G. T. and McBain, A. J. (1999) The human colonic microbiota. In: Colonic Microbiota, Nutrition and Health. G. R. Gibson and M. Roberfroid (Eds). Kluwer Academic Publishers, London, pp. 1-26.

Macfarlane, G. T., Gibson, G. R. and Cummings, J. H. (1992) Comparison of fermentation reactions in different regions of the human colon. Journal of Applied Bacteriology, 72, 57-64.

Macfarlane, S., McBain, A. J. and Macfarlane, G. T. (1997) Consequences of biofilm and sessile growth in the large intestine. Advances in Dental Research, 11, 59-68.

Macfarlane, G. T., Macfarlane, S. and Gibson, G. R. (1998) Validation of a three-stage compound continuous culture system for investigating the effect of retention time on the ecology and metabolism of bacteria in the human colon. Microbial Ecology, 35, 180-187.

Marteau, P., de Vrese, M., Cellier, C. J. and Schrezenmeir, J. (2001) Protection from gastrointestinal diseases with the use of probiotics. American Journal of Clinical Nutrition, 73 (Suppl.), 430S436S.

McBain, A. J. and Macfarlane, G. T. (2001) Modulation of genotoxic enzyme activities by nondigestible oligosaccharide metabolism in in-vitro human gut bacterial systems. Journal of Medical Microbiology, 50, 833-842.

McCartney, A. L. (2002) Application of molecular biological methods for studying probiotcs and the gut flora. British Journal of Nutrition, 88, S29-S37. 
Metchnikoff, E. (1907) The Prolongation of life. Heinemann, London.

Miller, T. L. and Wolin, M. J. (1981) Fermentation by the human large intestine microbial community in an in vitro semicontinuous culture system. Applied Environmental Microbiology, 42, 400-407.

Mitsuoka, T. (1990) Bifidobacteria and their role in human health. Journal of Industrial Microbiology, 6, 263-268.

Mitsuoka, T., Hidaka, H. and Eida, T. (1987) Effect of fructooligosaccharides on intestinal microflora. Die Nahrung, 31, 427-436.

Modler, H. W. (1994) Bifidogenic factors - sources, metabolism and applications. International Dairy Journal, pp. 383-407.

Molly, K., Vande Woestyne, M. and Verstraete, W. (1993) Development of a 5-step multi-chamber reactor as a simulation of the human intestinal microbial ecosystem. Applied Microbiology and Biotechnology, 39, 254-258.

Moore, W. E. C., Cato, E. P. and Holdeman, L. V. (1978) Some current concepts in intestinal bacteriology. American Journal of Clinical Nutrition, 31, S33-S42.

Morgan, A. J., Mul, A. J., Beldman, G. and Voragen, A. G. J. (1992) Dietary oligosaccharides - new insights. AGRO Food Industry High Technology, Nov/Dec, 35-38.

Morisse, J. P., Maurice, R., Boilletot, E. and Cotte, J. P. (1993) Assessment of the activity of a fructooligosaccharide on different caecal parameters in rabbits experimentally infected with $E$. coli 0.103. Annals of Zootechnology, 42, 81-87.

Naruszewicz, M., Johansson, M.-L., Zapolska-Downar, D. and Bukowska, H. (2002) Effect of Lactobaillus plantarum 299v on cardivascular disease risk factors in smokers. American Journal of Clinical Nutrition, 76, 1249-1255.

Nilsson, U., Oste, R., Jagerstad, M. and Birkhed, D. (1988) Cereal fructans: in vitro and in vivo studies on availability in rats and humans. Journal of Nutrition, 118, 1325-1330.

Oku, T., Tokunaga, T. and Hosoya, N. (1984) Nondigestibility of a new sweetener, 'Neosugar' in the rat. Journal of Nutrition, 114, 1574-1581.

Olano-Martin, E., Mountzouris, K. C., Gibson, G. R. and Rastall, R. A. (2000) In vitro fermentability of dextran, oligodextran and maltodextrin by human gut bacteria. British Journal of Nutrition, 83, $247-255$.

O'Sullivan, M. G. (1996) Metabolism of bifidogenic factors by gut flora - an overview. Bulletin of International Dairy Foundation, 313, 23-25.

Ouwehand, A. C., Salmien, S. and Isolauri, E. (2002) Probiotics: an overview of the beneficial effects. Antonie van Leeuwenhoek, 82, 279-289.

Park, S. F. and Kroll, R. G. (1993) Expression of listeriolysin and phosphatidylinositol-specific phospholipase $\mathrm{C}$ is repressed by the plant-derived molecule cellobiose in Listeria monocytogenes. Molecular Microbiology, 8, 653-661.

Payne, S., Gibson, G., Wynne, A., Hudspith, B., Brostoff, J. and Tuohy, K. (2003) In vitro studies on colonization resistance of the human but microbiota to Candida albicans and the effects of tetracycline and Lactobacillus plantarum LPK. Current Issues in Intestinal Microbiology, 4, 1-8.

Pereira, D. I. A. and Gibson, G. (2002) Cholesterol assimilation by lactic acid bacteria and bifidobacteria isolated from the human gut. Applied and Environmental Microbiology, 68, 4689-4693.

Pereira, D. I. A., McCartney, A. L. and Gibson, G. R. (2003) An in vitro study of the probiotic potential of a bile-salt-hydolysing Lactobacillus fermentum strain, and determination of its cholesterol-lowering properties. Applied and Environmental Microbiology, 69, 4743-4752.

Quigley, M. E. and Kelly, S. M. (1995) Structure, function and metabolism of host mucus glycoproteins. In: Human Colonic Bacteria - Role in Nutrition, Physiology and Pathology. G. R. Gibson and G. T. Macfarlane (Eds). CRC Press, London, pp. 175-199.

Rao, A. V. (1999) Large bowel cancer and colonic foods. In: Colonic Microbiotia, Nutrition and Health. G. R. Gibson and M. Roberfroid (Eds). Kluwer Academic Publishers, London, pp. 257-268.

Rastall, R. A. and Maitin, V. (2002) Prebiotics and synbiotics: towards the next generation. Current Opinion in Biotechnology, 13, 490-496. 
Reddy, B. S. (1999) Possible mechanisms by which pro- and prebiotics influence colon carcinogenesis and tumour growth. Journal of Nutrition, 129, 1478S-1482S.

Roberfroid, M. (1998) Prebiotics and synbiotics: concepts and nutritional properties. British Journal of Nutrition, 80 (Suppl. 2), 197S-202S.

Roberfroid, M. (2002) Functional food concept and its application to prebiotics. Digestive and Liver Disease, 34, S105-S110.

Roberfroid, M., Gibson, G. R. and Delzenne, N. (1993) The biochemistry of oligofructose, a nondigestible fibre: an approach to calculate its calorific value. Nutrition Reviews, 51, 137-146.

Roitt, I., Brostoff, J. and Male, D. (1998) Immunology. Mosby, London.

Roller, M., Rechkemmer, G. and Watzl, B. (2004) Prebiotic inulin enriched with oligofructose in combination with the probiotics Lactobacillus rhamnosus and Bifidobacterium lactis modulates immune function in rats. Journal of Nutrition, 134, 153-156.

Rosenfeldt, V., Benfeldt, E., Nielsen, S. D., F., M. K., Jeppesen, D. L., Valerius, N. H. and Paeregaard, A. (2003) Effect of probiotic Lactobacillus strains in children with atopic dermatitis. Journal of Allergy and Clinical Immunology, 111, 389-395.

Rowland, I. R. (Ed.) (1988) Role of the Gut Flora in Toxicity and Cancer. Academic Press, London.

Rowland, I. R. and Mallett, A. K. (1990) The effect of diet on mammalian gut flora and its metabolic activities. CRC Critical Reviews in Toxicology, 16, 31-103.

Rowland, I. R. and Tanaka, R. (1993) The effects of transgalactosylated oligosaccharides on gut flora metabolism in rats associated with human faecal microflora. Journal of Applied Bacteriology, 74, 667-674.

Rowland, I. R. and Wise, A. (1985) The effect of diet on the mammalian gut flora and its metabolic activities. CRC Critical Reviews in Toxicology, 16, 31-103.

Rumney, C. J. and Rowland, I. R. (1992) In vivo and in vitro models of the human colonic flora. Critical Reviews in Food Science and Nutrition, 34, 229-311.

Rumney, C. J., Rowland, I. R., Coutts, C. M., Randerath, K., Reddy, R., Shah, A. B., Ellul, A. and O'Neil, I. K. (1993) Effects of risk-associated human dietary macrocomponents on processes related to carcinogenesis in human-flora-associated (HFA) rats. Carcinogenesis, 14, 79-84.

Rycroft, C. E., Fooks, L. J. and Gibson, G. R. (1999) Methods for assessing the potential of prebiotics and probiotics. Current Opinion in Clinical Nutrition and Metabolic Care, 2, 481-484.

Rycroft, C. E., Jones, M. R., Gibson, G. R. and Rastall, R. A. (2001) A comparative in vitro evaluation of the fermantation properties of prebiotic oligosaccharides. Journal of Applied Microbiology, 91, 878-887.

Saarela, M., Lahteenmaki, L., Crittenden, R., Salmien, S. and Mattila-Sandholm, T. (2002) Gut bacteria and health foods - the European perspective. International Journal of Food Microbiology, 78, 99-117.

Salminen, S. and Salminen, E. (1997) Lactulose, lactic acid bacteria, intestinal microecology and mucosal protection. Scandinavian Journal of Gastroenterology, 32 (Suppl.), 45-48.

Salminen, S., Bouley, C., Boutron-Ruault, M-C., Cummings, J. H., Franck, A., Gibson, G. R., Isolauri, E., Moreau, M. C., Roberfroid, M. B. and Rowland, I. R. (1998a) Functional food science and gastrointestinal physiology and function. British Journal of Nutrition, 80, S147-S171.

Salminen, S., von Wright, A., Morelli, L., Marteau, P., Brassart, D., de Vos, W. M., Fonden, R., Saxelin, M., Collins, K., Mogensen, G., Birkeland, S.-E. and Mattila-Sandholm, T. (1998b) Demonstation of the safety of probiotics - a review. International Journal of Food Microbiology, 44, 93-106.

Salminen, M. K., Tynkkynen, S., Rautelin, H., Saxelin, M., Vaara, M., Ruutu, P., Sarna, S., Valtonen, V. and Jarvinen, A. (2002) Lactobacillus bacteremia during a rapid increase in probiotic use if Lactobacillus rhamnosus GG in Finland. Clinical Infectious Diseases, 35, 1155-1160.

Salyers, A. A. and Whitt, D. D. (1994) In: Bacterial Pathogenesis: a Molecular Approach. ASM Press, Washington, DC, pp. 130-140.

Satokari, R. M., Vaughn, E. E., Akkermans, A. D. L., Saarela, M. and de Vos, W. M. (2001) Polymerase chain reaction and denaturing gradient gel electrophoesis monitoring of faecal Bifidobacterium populations in a prebiotic and probiotic feeding trial. Systemic and Applied Microbiology, 24, 227-231. 
Schriffin, E. J. and Brassart, D. (1999) Intestinal microflora and the mucosal mechanisms of protection. In: Colonic Microbiota, Health and Disease. G. R. Gibson and M. Roberfroid (EDs). Kluwer Academic Publishers, London, pp. 201-212.

Shin, H.-S., Lee, J.-H., Pestka, J. J. and Ustunol, Z. (2000) Growth and viability of commercail Bifidobacterium spp. in skim milk containing oligosaccharides and inulin. Journal of Food Science, 65, 884-887.

Silvi, S., Rumney, C. J., Cresci, A. and Rowland, I. R. (1999) Resistant starch modifies gut flora and microbial metabolismin human flora-associated rats inoculated with feaces from Italian and UK donors. Journal of Applied Microbiology, 86, 521-530.

Simon, G. L. and Gorbach, S. L. (1984) Intestinal flora in health and disease. Gastroenterology, 86, 174-193.

Sullivan, A. and Nord, C. E. (2002) The place of probiotics in human intestinal infections. International Journal of Antimicrobial Agents, 20, 313-319.

Sullivan, N. M., Mills, D. C., Riemann, H. P. and Arnon, S. S. (1988) Inhibition of growth of Clostriduim botulinum by intestinal microflora isolated from healthy infants. Microbial Ecology in Health and Disease, 1, 179-192.

Tannock, G. W., Munro, K., Harmslen, H. J. M., Welling, G. W., Smart, J. and Gopal, P. K. (2000) Analysis of the faecal microflora of human subjects consuming a probiotic product containing Lactobacillus rhamnosus DR20. Applied and Environmental Microbiology, 66, 2578-2588.

Teuri, U. and Korpel, R. (1998) Galacto-oligosaccharides relieve constipation in elderly people. Annals of Nutrition and Metabolism, 42, 319-327.

Topping, D. L. and Clifton, P. M. (2001) Short-chain fatty acids and human colonic function: roles of resistant starch and nonstarch polysaccharides. Physiological Reviews, 81, 1031-1064.

Tuohy, K. M., Finlay, R. K., Wynne, A. G. and Gibson, G. R. (2001a) A human volunteer study on the prebiotic effects of HP-inulin - gut bacteria enumerated using fluorescent in situ hybridisation (FISH). Anaerobe, 7, 113-118.

Tuohy, K. M., Kolida, S., Lustenberger, A. and Gibson, G. R. (2001b) The prebiotic effects of biscuits containing partially hydrolyzed guar gum and fructooligosaccharides - a human volunteer study. British Journal of Nutrition, 86, 341-348.

Tuohy, K. M., Ziemer, C. J., Klinder, A., Knobel, Y., Pool-Zobel, B. L. and Gibson, G. R. (2002) A human volunteer study to determine the prebiotic effects of lactulose powder on human colonic bacteria. Microbial Ecology in Health and Disease, 14, 165-173.

Van Loo, J., Cummings, J., Delzenne, N., Englyst, H., Franck, A., Hopkins, M., Kok, N., Macfarlane, G., Newton, D., Quigley, M., Roberfroid, M., Van Vliet, T. and Van den Heuvel, E. (1999) Functional food properties of non-digestible oligosaccharides: a consensus report from the ENDO project (DGXII AIRII-CT94-1095. British Journal of Nutrition, 81, 121-132.

Wolever, T. M. S., Spadafora, P. and Eshuis, H. (1991) Interaction between colonic acetate and propionate in humans. American Journal of Clinical Nutrition, 53, 681-687.

Wolf, B. W., Garleb, K. A., Ataya, D. G. and Casas, I. A. (1995) Safety and tolerance of Lactobacillus reuteri in healthy adult male subjests. Microbial Ecology in Health and Disease, 8, 41-50.

Yamamoto-Osaki, T., Kamiya, S., Sawamura, S., Kai, M. and Ozawa, A. (1994) Growth inhibition of Clostridium difficile by intestinal flora of infant faeces in continuous flow culture. Journal of Medical Microbiology, 40, 179-187.

Yuki, N., Watanabe, K., Mike, A., Tagami, Y., Tanaka, R., Ohwaki, M. and Morotomi, M. (1999) Survival of a probiotic, Lactobacillus casei strain Shirota, in the gastrointestinal tract: selective isolation from faeces and identification using monoclonal antibodies. International Journal of Food Microbiology, 48, 51-57.

Zetterström, R., Bennett, R. and Nord, K.-E. (1994) Early infant feeding and micro-ecology of the gut. Acta Paediatric Japonica, 36, 562-571. 